\title{
Etiopathogenesis of sacroiliitis: implications for assessment and management
}

\author{
Manuela Baronio ${ }^{1}$, Hajra Sadia ${ }^{2}$, Stefano Paolacci ${ }^{3}$, Domenico Prestamburgo ${ }^{4}$, Danilo Miotti ${ }^{5}$, \\ Vittorio A. Guardamagna ${ }^{6}$, Giuseppe Natalini ${ }^{1}$, and Matteo Bertelli $i^{3,7,8}$
}

'Dipartimento di Anestesia, Rianimazione, Terapia Intensiva e del Dolore, Fondazione Poliambulanza, Brescia, Italy ${ }^{2}$ Atta-ur-Rahman School of Applied Biosciences, National University of Science and Technology, Islamabad, Pakistan ${ }^{3} M A G I ' s$ Lab, Rovereto, Italy

${ }^{4}$ Ortopedia e Traumatologia, Ospedali Civili di Legnano e Cuggiono, Cuggiono, Italy

${ }^{5}$ Cure Palliative e Terapia del Dolore, ICS Maugeri, Pavia, Italy

${ }^{6}$ Cure Palliative e Terapia del Dolore, IRCCS IEO, Milano, Italy

${ }^{7} M A G I$ Euregio, Bolzano, Italy

${ }^{8}$ EBTNA-LAB, Rovereto, Italy

Received January 16, 2020

Revised March 17, 2020

Accepted April 16, 2020

Handling Editor: Kyung Hoon Kim

\section{Correspondence}

Stefano Paolacci

MAGl's Lab, Via delle Maioliche, 57/D,

Rovereto, Trentino 38068, Italy

Tel: +39-0464420795

Fax: +39-0464420795

E-mail: stefano.paolacci@assomagi.org
The sacroiliac joints connect the base of the sacrum to the ilium. When inflamed, they are suspected to cause low back pain. Inflammation of the sacroiliac joints is called sacroiliitis. The severity of the pain varies and depends on the degree of inflammation. Sacroiliitis is a hallmark of seronegative spondyloarthropathies. The presence or absence of chronic sacroiliitis is an important clue in the diagnosis of low back pain. This article aims to provide a concise overview of the anatomy, physiology, and molecular biology of sacroiliitis to aid clinicians in the assessment and management of sacroiliitis. For this narrative review, we evaluated articles in English published before August 2019 in PubMed. Then, we selected articles related to the painful manifestations of the sacroiliac joint. From the retrieved articles, we found that chronic sacroiliitis may be caused by various forms of spondyloarthritis, such as ankylosing spondyloarthritis. Sacroiliitis can also be associated with inflammatory bowel disease, Crohn's disease, gout, tuberculosis, brucellosis, and osteoarthritis, indicating common underlying etiological factors. The pathophysiology of sacroiliitis is complex and may involve internal, environmental, immunological, and genetic factors. Finally, genetic factors may also play a central role in progression of the disease. Knowing the genetic pre-disposition for sacroiliitis can be useful for diagnosis and for formulating treatment regimens, and may lead to a substantial reduction in disease severity and duration and to improved patient performance.

Key Words: Inflammation; Inflammatory Bowel Diseases; Low Back Pain; Sacroiliac Joint; Sacroiliitis; Sacrum; Spondylitis, Ankylosing; Spondyloarthropathies.

\section{INTRODUCTION}

Sacroiliitis is a painful inflammation of the sacroiliac joint which is particularly challenging to diagnose [1]. Sacroi- liitis is linked to inflammatory arthritis of the spine. The inflammation may have different causes, including autoimmunity, microtrauma, exercise, and in some cases, infections. Sacroiliitis can also be associated with Crohn's (a) This is an open-access article distributed under the terms of the Creative Commons Attribution Non-Commercial License (http://creativecommons.org/licenses/by-nc/4.0/), which permits unrestricted non-commercial use, distribution, and reproduction in any medium, provided the original work is properly cited.

(C) The Korean Pain Society, 2020
Author contributions: Manuela Baronio: Writing/manuscript preparation; Hajra Sadia: Writing/manuscript preparation; Stefano Paolacci: Writing/ manuscript preparation; Domenico Prestamburgo: Writing/manuscript preparation; Danilo Miotti: Writing/manuscript preparation; Vittorio A. Guardamagna: Writing/manuscript preparation; Giuseppe Natalini: Writing/manuscript preparation; Matteo Bertelli: Study conception. 
disease, inflammatory bowel disease, ulcerative colitis, and gout. Different diagnostic techniques are available for joint inflammation. Imaging techniques, such as simple radiography, can show narrowing of the joint space, fusion, bone erosion, and hardening of the ligaments. If not properly diagnosed and managed, sacroiliitis may become chronic. Maintenance of muscle strength supports and stabilizes the sacroiliac joints, increases muscle flexibility, and makes standing, sitting, bending, lifting, and walking less painful [2].

There is increasing interest in the musculoskeletal system for pain management and rehabilitation. However, the treatment of sacroiliitis requires a better understanding of sacroiliac joint anatomy, and more sensitive clinical and physical examination techniques.

This article reviews the etiological agents of sacroiliitis and associated diseases, as well as its genetic and immunological basis.

\section{MAIN BODY}

\section{Anatomy and physiology of the sacroiliac joint}

The sacroiliac joints connect the sacrum to the ilium. They facilitate absorption of vertical forces from the spine and transmit them to the pelvis and lower body parts [3], and also allow forces to be transmitted from lower body to the spine [4]. The sacroiliac joint is $1-2 \mathrm{~mm}$ wide. This diarthrodial joint has two bony surfaces, the sacrum (convex) and the ilium (concave), and its motion ranges from 2 to 3 degrees. There are two sacroiliac joints, one on each side (left and right), and they may differ considerably from person to person [5]. The auricular surfaces of the bones of the sacrum and ilium are separated by a joint space (0.5$4 \mathrm{~mm}$ ) containing synovial fluid, and are enclosed by a fibrous capsule [6].

During different body movements, the joint moves in the transverse and longitudinal planes $[7,8]$.

Clinicians have different opinions about the movement of the joint and how much mobility should be considered 'normal', as it varies from person to person. Backward and downward gliding movement of the ipsilateral ilium causes flexion of the hip, while extension occurs when the ilium moves forward and away from the sacrum [9].

The ligaments of the sacroiliac joint include the anterior sacroiliac, interosseous sacroiliac, posterior sacroiliac, and the extrinsic sacroiliac joint ligaments [9]. A close anatomical relationship exists between the long posterior sacroiliac ligament, the erector spinae muscle, the posterior layer of the thoracolumbar fascia, and part of the sacrotuberous ligament. The main part of the sacrotuberous liga- ment connects the sacrum with the ischial tuberosity [10]. The extrinsic sacroiliac joint ligaments limit the flexion of the sacrum, whereas the interosseous ligaments run vertically from ilium to sacrum [11]. During pregnancy, there is increased production of relaxin, a hormone involved in loosening ligaments and the symphysis pubis. This enables the wide opening of the pelvic joint during childbirth [12].

The sacroiliac joint can produce pain but its exact innervation is still unclear [13]. Cunningham's Textbook of Anatomy [14] states that "the sacroiliac joint is supplied: 1) by twigs directly from the sacral plexus and the dorsal ramus of the first two sacral nerves; and 2) by branches from the superior gluteal and obturator nerves" [15]. Holm et al. [16] proposed an innervation model of the sacroiliac joint in which the major innervation of the joint involves the L4-S1 nerve roots. Posterior rami of L4-S3 innervate the posterior side through its lateral branches while the L2-S2 segments innervate the anterior side. Successful attenuation of sacroiliac joint pain has been reported by Patel et al. [17] after neurotomy of the L5 dorsal primary ramus. By this technique, they also found involvement of lateral branches of the dorsal sacral rami from S1-S3 in sacroiliac joint pain. The sacroiliac joints contain myelinated and unmyelinated nerve fibres along with encapsulated endings. The diameter of many axons that innervate the joint is about 0.2-2.5 mm [9]. Axons with these anatomical and physiological properties have been associated with nociception in other areas and may be involved in perception of pain from the sacroiliac joint.

In early life, the sacroiliac joint surfaces are flat or regular. As the body starts moving/walking, load is transmitted to the lower body through the sacroiliac joint. The joint surfaces then lose planar topology and angular orientations arise [5]. An elevated ridge develops along the iliac surface and a depression along the sacral surface. This, in turn, increases joint stability and makes dislocations very rare [18]. With age, the joint space decreases, becomes more irregular and is filled with debris. During aging, there is no fusion of the joint [19]. As the joint fills with debris, it becomes stiffer and does not respond well to trauma. This, along with decreased bone mineral density, predisposes the elderly to stress fractures due to a weakened sacral bone [20]. Various anatomical variants of the sacroiliac joint have been reported by different researchers. Prassopoulos et al. [21] classified anatomic variants as accessory joint, iliosacral complex, bipartite iliac bony plate, crescent-like iliac bony plate, semicircular defects, and ossification centers. All these variants occurred in different patients and each patient's joint had a distinct appearance. 


\section{Clinical signs of sacroiliitis}

Low back pain is a common clinical manifestation, affecting approximately $70 \%$ of people at some stage of their life [22]. Pain in the sacroiliac joint and surrounding structures can present as low back, pelvic, gluteal, or sacral pain in patterns that vary widely. The pain may be described as sensations such as numbness, popping, or clicking pain usually below the beltline. Moreover, it could be referred to the groin [4]. It may be uni- or bi-lateral, though unilateral is four times more frequent than bilateral pain. People that practice sports or do jobs involving unilateral loading of the legs are at higher risk of low back pain [23].

Although a specific cause of chronic low back pain can be identified in about $75 \%$ of patients, low back pain is usually considered idiopathic [24]. Dysfunction of the sacroiliac joint is a major source of such pain and may account for as much as $20 \%$ of complaints of low back pain in the general population [25]. The pathological conditions causing sacroiliac joint dysfunction are inflammatory and mechanical. The mechanical condition, referred to as sacroiliac joint syndrome, usually emerges from minor subluxations and/or ligamentous strain in the joint, although the exact mechanism is unclear [10]. Sacroiliitis can also be caused by ankylosing spondylitis. Ankylosing spondylitis is characterized by fibrosis and ossification of ligaments and capsules, and primarily affects the spine ( $100 \%$ of cases), intervertebral joints $(75 \%)$, shoulders $(30 \%)$, and knees (20\%) [26].

\section{1) Diagnosis}

Sacroiliitis is difficult to detect. Fractures, tumors, and joint structural alterations can be assessed by pelvic X-ray [27]. Early detection methods include bone scans, but they cannot distinguish mechanical from bacterial septic sacroiliitis [28].

Magnetic resonance imaging (MRI) appears to be useful for evaluating the sacroiliac joints of patients with low back pain. Fluid in the joint, bone marrow edema and soft tissue swellings can be identified by MRI. The diagnostic sensitivity of MRI for sacroiliitis is about 54\% [29]. The Spondyloarthritis International Society has developed assessment criteria for the diagnosis of sacroiliitis in spondyloarthritis. MRI can identify inflammatory changes of the joint at very early stages $[30,31]$ and can thus help in the management and treatment of complex diseases such as ankylosing spondylitis [31]. MRI can also differentiate between rheumatic and non-rheumatic changes in the sacroiliac joint [32].

Single-photon emission computed tomography and bone scintigraphy can be used for assessment of sacro- iliac joint pathology but are not routinely practiced [33]. The current gold standard for diagnosis of sacroiliac joint dysfunction is injection of a local anesthetic solution into the joint guided by fluoroscopy or computed tomography: if the injection relieves pain, the sacroiliac joint can be confirmed as the pain source. The simultaneous analysis of bone computed tomography scans and radiography can help diagnose joint changes and progression of disease with an accuracy up to $95 \%$ [34].

Although most patients with an accessory sacroiliac joint do not complain of chronic low back pain, they may have chronic buttock or low back pain, especially with severe arthritis and degenerative changes. Using computed tomography to assess low back pain, accessory sacroiliac joints have been identified as the cause of pain in $4.5 \%$ of patients under 40 years [35]. In one case, a patient was diagnosed with an accessory sacroiliac joint and had severe arthritic changes in the right sacroiliac joint [36]. Another case of an accessory sacroiliac joint was misdiagnosed as ankylosing spondylitis or spondyloarthritis, because the patient was under 45 years, had pain prior to the appearance of degenerative changes, and developed arthritic changes due to the accessory sacroiliac joint over a period of 7 years [37]. An accessory sacroiliac joint may therefore be a cause of sacroiliac pain and should be included in differential diagnosis for better management of the disease.

\section{2) Sacroiliitis}

In most cases, sacroiliac joint dysfunction is seen as a result of micro-trauma. Acute or repetitive microtrauma may cause low back pain in $10 \%-30 \%$ of patients [2]. The trauma mostly results from physical activities like heavy lifting or prolonged bending, or may be a result of a rearend motor vehicle collision [38]. The pain can be managed through activity modification, medication, physical therapy, and/or injections. In cases of prolonged sacroiliac joint pain, clinicians should look for other potential etiologies. Sudden rotation and/or axial strain is the most common mechanism underlying acute sacroiliac joint pain [39]. People involved in physical activities requiring repetitive and/or asymmetric body movements are at high risk [40].

An example of an activity that involves asymmetric body movements is rowing. In fact, during rowing, the transverse plane load is applied through the lumbosacral region while the pelvis remains relatively inactive. This disrupts normal equilibrium and results in unbalanced muscle action around the pelvic and sacroiliac region. A study on rowing teams reported a $>50 \%$ prevalence of sacroiliac joint dysfunction in rowers tested by the standing flexion test, and an examination of anatomical landmarks [41]. Similarly, other sports involving asymmetric techniques 
such as V-skating can also lead to lumbosacral dysfunction [42].

Low back pain is also rarely reported in children aged 5 (1\%) to 15 years $(53 \%)$ [43]. A strong positive association between adolescent idiopathic scoliosis, abnormal curvature of the spine, and sacroiliac joint dysfunction was observed in athletes up to 17 years of age in a case-control study [44]. Seronegative spondyloarthropathy and ankylosing spondylitis were reported in a young male athlete who did running, jumping, and weightlifting. The case was initially misdiagnosed as sacroiliac joint instability and sacroiliac joint dysfunction; later a stress fracture was diagnosed [45]. In addition to these specific examples, other sporting activities involving biomechanical stress on the spine and pelvis can cause low back pain, sacroiliac joint dysfunction, and related diseases. As the lumbospinal region connects the torso and the lower extremities, it is at high risk of athletic injury since most sports stress this region.

\section{3) Treatment options}

Conservative treatment of sacroiliitis involves management of pain with activity modification, physiotherapy, manual manipulation, topical medication such as lidocaine and diclofenac, and oral medication, usually nonsteroidal anti-inflammatory drugs $[2,46]$. Complementary treatment regimens can also be helpful in pain management but cannot be considered treatment options for sacroiliac joint pain [2]. Massage, yoga, and acupuncture are thought to relieve the pain; the effect is not long-lasting but can complement conservative treatment. Treatment goals for spondyloarthritis not only include management of symptoms but also treatment of underlying dysfunction [40].

Osteopathic and other manipulative treatment include manual techniques used to treat or prevent injury or illness. Muscles and joints are moved using stretching, resistance, and applying gentle pressure to periarticular structures. Osteopaths, chiropractors, physical therapists, and athletic trainers use various forms of osteopathic manipulative treatments, depending on their specialties [33]. Up to $95 \%$ of patients respond to such treatments and show excellent short-term results. Long-term benefits and recurrence prevention after osteopathic manipulative treatment have not yet been proved [33].

Interventional treatment may include neurostimulation, joint injections, radiofrequency denervation, and joint fusion. Neurostimulation provides pain relief through modulation of the nervous system. Among neurostimulatory therapies, peripheral nerve field stimulation is used for sacroiliac joint pain. Two permanent subcutaneous electrodes are implanted in the upper buttock below the iliac crest. Neurostimulation is used in patients in which pharmacological or physical therapies have failed. The mechanism of action of peripheral nerve field stimulation is unknown, although a number of hypotheses have been put forward: inhibition of the pain pathway through the counter-stimulation of the sensory fibers that innervate the affected region, changes in endorphins and other neurotransmitter release, as well as local blood flow changes $[47,48]$.

Corticosteroids can be injected into the sacroiliac joint to reduce inflammation and pain [49]. However, there is no clear evidence that they are actually effective $[50,51]$. Furthermore, too many injections may weaken bones and tendons, therefore the administration can be performed only a few times per year [52].

Radio frequency denervation (or neurotomy) consists of an insulated needle electrode with the exposed tip adjacent to the nerve branches that reach the target joints. The radio frequency applied to the electrode heats the adjacent tissues and ablates the nerve that innervates the joint. The effectiveness of this technique has not been clearly established in randomized controlled trials [53].

In severe cases, fusing the two bones together with a metal device may be used to treat sacroiliitis. The implant placement is performed under general anesthesia. The ilium is reached after an incision in the buttock region, and the dissection of the gluteal fascia. After that, the sacrum is reached using a drill through the iliac bone to the sacrum. At the end of this procedure, three implants are placed. The upper implant is placed within the ala of sacrum. The other two implants are located adjacent to the S1 foramen, and between the S1 and S2 foramina, respectively [54]. Since the pain is caused by the movement of the sacroiliac joint, it is reasonable to think that blocking this joint, through the sacroiliac joint fusion, would result in a reduction of pain. The implant placement is performed under general anesthesia. The ilium is reached after an incision in the buttock region and the dissection of the gluteal fascia. After that, the sacrum is reached through the use of a drill that punches the iliac bone to the sacrum. At the end of this procedure, three implants are placed. The upper implant is placed within the ala of sacrum. The other two implants are located adjacent to the S1 foramen, and between the S1 and S2 foramina, respectively [54]. This technique seems to be highly effective at reducing pain [55-57].

\section{Molecular biology of sacroiliitis}

Sacroiliac arthropathies are known to be highly recurrent within families. First-degree relatives are at high risk of developing ankylosing spondylitis, about 52 times higher 
than unrelated individuals [58]. The association of environmental and genetic factors in ankylosing spondylitis was unclear until the early 1970s, when the human leukocyte antigen-B27 (HLA-B27) allele was found to be associated with the disease $[59,60]$.

\section{1) MHC and non-MHC associations}

HLA-B27 in major histocompatibility complex (MHC) class I contributes to immune system dysfunction. There is a strong association between the HLA-B27 gene and ankylosing spondylitis, one of the strongest links of a gene with a human disease, although the underlying molecular mechanism is still unclear. Association of HLA-B27 with autoimmune diseases has been widely studied and 130 subtypes of HLA-B27 have now been reported. Since most patients with Crohn's disease have symptoms of low back pain and sacroiliitis, positivity for HLA-B27 in these patients places them at high risk of developing axial inflammation [61]. However, the relation of HLA-B27 with sacroiliitis needs more extensive research, since some reports suggest a lack of association, as no antibodies were found in patients with inflammatory low back pain [62] or isolated sacroiliitis [61]. Another report demonstrates a weaker association of HLA-B27 in inflammatory bowel diseaseassociated spondyloarthritis than in idiopathic ankylosing spondylitis [63].

In a case report, Eksioglu et al. [64] postulated that use of isotretinoin might trigger sacroiliitis in combination with HLA-B27 positivity, although this was not confirmed in other cases. In another study, Kașifoğlu et al. [65] observed that $32.7 \%$ of patients with familial Mediterranean fever had symptoms of sacroiliitis, $47 \%$ of whom were also HLA-B27 positive. This data suggests possible involvement of HLA-B27 in the development of sacroiliitis and in the severity of seronegative spondyloarthropathy. Though extensively studied, the contribution of HLA-B27 to the genetic risk of developing spondyloarthritis is minimal. Polymorphisms in genes outside the MHC class I region have also been found to be associated with development of sacroiliitis and ankylosing spondylitis. These involve various cytokines, such as interleukin 1 (IL-1) and its receptor IL-1R, IL-23, and tumor necrosis factor $\alpha(\mathrm{TNF} \alpha)$ [66].

Although IL-1 could be implicated in sacroiliitis, there is no direct evidence of its presence in joint biopsies. Genes encoding IL-1 $\alpha$, IL-1 $\beta$, and IL-1 receptor antagonist (IL1RA) contain various polymorphic sites which affect the production of cytokines, and are involved in joint destruction [66]. Linkage studies have shown that the long arm of chromosome 2 has a strong correlation with the development of ankylosing spondylitis. As the IL-1 family of genes is located on 2q13, their alleles could be useful markers for genes potentially involved in the pathogenesis of this disease [67]. The IL-1RA binds IL-1, competitively inhibits IL-1 binding with its own receptor, and prevents signaling through the IL-1 receptor [68]. Studies have shown that disruption of the IL-1 signaling cascade prevents bone damage and joint erosion in animal rheumatoid arthritis models $[66,69]$. The gene encoding IL-1RA has a variable number of tandem repeats in intron 2. Based on the number of repeats, different alleles have been identified. An allele with two repeat sequences (allele 2 of IL-1R) is known to increase production of IL-1RA in vitro [67]. Studies in human subjects have also shown a high frequency of allele 2 of IL-1RA in ankylosing spondylitis patients compared to healthy controls. Although no difference in the preferred polymorphic allele of the IL-1 $\alpha$ and IL-1 $\beta$ genes was observed in this study [70], association of polymorphisms of IL- $1 \alpha$ and IL-1 $\beta$ with ankylosing spondylitis susceptibility has been observed in the Han Chinese population [71].

Polymorphism of the IL23R gene and surrounding regulatory region shows a strong association with risk of ankylosing spondylitis [72,73], inflammatory bowel disease [74], and psoriasis [75]. An association between rs11209026 and ankylosing spondylitis was observed by Kadi et al. [76] in the French population. However, this association was limited to spondyloarthritis patients with radiographic sacroiliitis. This finding reinforces the evidence that IL23 is involved in the development and progression of these diseases, and suggests that IL-23 may be the key cytokine controlling many disease manifestations of ankylosing spondylitis and other spondyloarthropathies [76].

Proinflammatory cytokine TNF is involved in inflammatory conditions such as sacroiliitis, psoriatic arthritis, rheumatoid arthritis, ulcerative colitis, and Crohn's disease. Overexpression of TNF may cause sacroiliitis, as TNF blockade treatment in patients with ankylosing spondylitis has been demonstrated to bring significant benefits and outcomes [77,78]. Development of bilateral erosive sacroiliitis with synovial inflammation, bone erosion, and cartilage destruction have also been observed in transgenic mice overexpressing TNF. These inflammatory changes were inhibited when TNF was blocked using infliximab antibody and signs of sacroiliitis were reduced in treated mice compared to the wild-type [79].

Variants in the CARD15 gene have been linked to a higher susceptibility for Crohn's disease. An association was observed between CARD15 variants and the development of sacroiliitis, as an extraintestinal manifestation of Crohn's disease [80], although this could not be confirmed in subsequent studies [81]. 


\section{2) Autoantibodies}

Autoantibodies have a strong role in most autoimmune diseases; however, little information is available on their possible role in sacroiliitis compared to other rheumatic autoimmune diseases. Several autoantibodies targeting antigens from connective, skeletal, and muscle tissue have been identified in the blood of patients with ankylosing spondylitis [82]. One of the most studied autoantibodies in ankylosing spondylitis is the antibody targeting protein, phosphatase magnesium-dependent 1A (PPM1A), a serine/threonine protein phosphatase that suppresses bone morphogenetic protein and regulates Wnt signaling [83]. Overexpression of PPM1A dephosphorylates the transcription factor involved in skeletal and osteogenic development [84]. Significantly higher levels of antiPPM1A autoantibodies have been observed in patients with more advanced sacroiliitis. Additionally, a positive correlation between levels of antibodies and the Bath Ankylosing Spondylitis Disease Activity Index (BASDAI) has been found after treatment with anti-TNF agents. Similarly, higher levels of anti-PPM1A autoantibodies have been observed in the serum of transgenic rats predisposed to spondyloarthritis compared to controls. Increased levels of PPM1A in ankylosing spondylitis synovial tissue promoted osteoblast differentiation, whereas downregulation of PPM1A suppressed it. The data suggests that PPM1A may contribute to the pathogenic bone ankylosis typical of ankylosing spondylitis [85].

Anti-citrullinated cyclic peptide is commonly detected in rheumatoid arthritis patients and individuals with joint inflammation. These antibodies have also been detected in patients with various clinical presentations. For example, anti-citrullinated cyclic peptide was found in a patient initially diagnosed seropositive for rheumatoid arthritis with involvement of the sacroiliac joint. Another patient showed a clinical picture of rheumatoid arthritis after an Escherichia coli-positive urinary tract infection; and two patients had asymmetrical sacroiliitis, without peripheral joint involvement. In all cases, high titres of anti-citrullinated cyclic peptide were found. The report suggests an overlap between rheumatoid arthritis and spondyloarthritis, as well as an association of high titres of anticitrullinated cyclic peptide with asymmetrical sacroiliitis and reactive arthritis in patients with no peripheral small joint involvement [86].

\section{3) MicroRNAs}

In one study, Prajzlerová et al. [87] observed significantly higher expression of miR-29a-3p in patients with progressive spinal disease compared to healthy controls. No cor- relation between microRNA levels and BASDAI was found in these patients. Other microRNAs selected in this particular study included miR-146a-5p and miR-222-3p. They have an established role in extracellular matrix formation and inflammation. All these microRNAs have been associated with spinal changes and/or disease activity assessed by BASDAI in ankylosing spondylitis patients.

In another study, Huang et al. [88] observed significantly higher expression of miR-29a in peripheral blood mononuclear cells of ankylosing spondylitis patients than rheumatoid arthritis patients and healthy controls, while no significant difference was observed between the rheumatoid arthritis patients and healthy controls. Although this elevated expression was not correlated with the disease activity index of ankylosing spondylitis patients, miR-29a might be a useful diagnostic marker of new bone formation. Similarly, elevated expression of miR-29a, miR-17$5 p$, miR-27a, and miR-126-3p was observed in peripheral blood mononuclear cells of patients with axial spondyloarthritis. No other clinical features were correlated with these four microRNAs in patients with ankylosing spondylitis. The highest expression was observed for microRNA29a, which may therefore have potential as a diagnostic marker in axial spondyloarthritis [89].

\section{4) Microbiome}

The established relationship between joint inflammation, intestinal inflammation, and co-occurrence of these diseases is a captivating issue. Since sacroiliitis is closely linked with intestinal diseases like inflammatory bowel disease and Crohn's disease, gut microbiota might play an important role in its development. Ileocolonoscopy studies found involvement of the gut in $25 \%$ to $75 \%$ of spondyloarthritis patients depending on subtype. Follow-up studies have shown development of Crohn's disease in about $6 \%$ of these patients [90]. The findings have also been confirmed via abdominal scintigraphy with labeled leucocytes, showing signs of intestinal inflammation in 50\% of patients [91].

An association between classic enteropathogenic bacteria, i.e., Yersinia, Salmonella, Shigella, and Campylobacter, has been observed with post-infectious spondyloarthritis and rheumatoid arthritis [92,93]. Escherichia coli [94] and Clostridium difficile [95] have also been implicated in rheumatoid arthritis. The anti-inflammatory strain, Faecalibacterium prausnitzii seems depleted in spondyloarthritis, suggesting a probable effect on the immune system [96]. Specific bacterial strains have been found to play an important role in the pathogenesis of ankylosing spondylitis. These strains include Klebsiella pneumonia [97] and Bacteroides vulgatus [98]. The effect of host genetics in determining the human microbiome in health and disease 
is also important, and could promote understanding of the symbiotic relationship between host and microbiota diversity.

A shared immunological link has been proposed by Baeten et al. [99] in the form of two hypotheses. One is the homing hypothesis based on the aberrant localization of $\mathrm{T}$ cells (particularly CD8+ T cells) in synovial fluid after priming in the gut; the other is based on altered trafficking of CD163+ antigen presenting cells. These macrophages activate particular lymphocytes, increasing production of TNF- $\alpha$ and decreasing synthesis of IL-10. Cytokines other than TNF- $\alpha$ may also be involved in the pro-inflammatory cytokine cascade, as a large subset of patients with spondyloarthropathies and inflammatory bowel disease do not respond to anti-TNF- $\alpha$ therapy [99]. It is therefore crucial to understand the exact basis of shared inflammatory pathways, gut microbiota, and joint inflammation.

\section{CONCLUSIONS}

Sacroiliitis and spondyloarthropathies are common causes of low back pain in people involved in repetitive asymmetric activities. In assessing patients with pain in the low back, or radiating to the thigh and calf, the clinician must bear in mind the possibility of sacroiliac joint inflammation and accessory sacroiliac joints. Sacroiliitis is usually the first manifestation of more complex spondyloarthropathies like ankylosing spondylitis, inflammatory bowel disease, Crohn's disease, psoriasis, and rheumatic disease. No single diagnostic technique can detect sacroiliac joint dysfunction with high sensitivity and specificity. Available techniques like computed tomography scans or MRI cannot differentiate symptomatic from asymptomatic patients. This review aims to provide clinicians, physicians, and researchers with concise information on the anatomy, physiology, and genetics of the sacroiliac joint for a better understanding of the etiology of sacroiliitis in the general population. Knowing genetic pre-disposition for sacroiliitis can be useful for diagnosis and for formulating treatment regimens, and may lead to a substantial reduction in disease severity and duration, and to improved patient performance.

\section{CONFLICT OF INTEREST}

No potential conflict of interest relevant to this article was reported.

\section{FUNDING}

No funding to declare.

\section{ORCID}

Manuela Baronio, https://orcid.org/0000-0001-5485-4915

Hajra Sadia, https://orcid.org/0000-0001-5230-3466

Stefano Paolacci, https://orcid.org/0000-0002-5551-7520

Domenico Prestamburgo, https://orcid.org/0000-0002-0234-5497

Danilo Miotti, https://orcid.org/0000-0002-9853-0047

Vittorio A. Guardamagna, https://orcid.org/0000-0002-3554-8151

Giuseppe Natalini, https://orcid.org/0000-0002-0408-1966

Matteo Bertelli, https://orcid.org/0000-0002-7646-2872

\section{REFERENCES}

1. Buchanan BK, Varacallo M. Sacroiliitis [Internet]. Treasure Island (FL): StatPearls Publishing; 2020. Available at: http:// www.ncbi.nlm.nih.gov/books/NBK448141/.

2. Rashbaum RF, Ohnmeiss DD, Lindley EM, Kitchel SH, Patel VV. Sacroiliac joint pain and its treatment. Clin Spine Surg 2016; 29: 42-8.

3. Dietrichs E. Anatomy of the pelvic joints--a review. Scand J Rheumatol Suppl 1991; 88: 4-6.

4. Prather H, Hunt D. Conservative management of low back pain, part I. Sacroiliac joint pain. Dis Mon 2004; 50: 670-83.

5. Solonen KA. The sacroiliac joint in the light of anatomical, roentgenological and clinical studies. Acta Orthop Scand Suppl 1957; 27: 1-127.

6. McKenzie-Brown AM, Shah RV, Sehgal N, Everett CR. A systematic review of sacroiliac joint interventions. Pain Physician 2005; 8: 115-25.

7. Scholten PJ, Schultz AB, Luchies CW, Miller JA. Motions and loads within the human pelvis: a biomechanical model study. J Orthop Res 1988; 6: 840-50.

8. Harrison DE, Harrison DD, Troyanovich SJ. The sacroiliac joint: a review of anatomy and biomechanics with clinical implications. J Manipulative Physiol Ther 1997; 20: 607-17.

9. Vleeming A, Schuenke MD, Masi AT, Carreiro JE, Danneels L, Willard FH. The sacroiliac joint: an overview of its anatomy, function and potential clinical implications. J Anat 2012; 221: 537-67.

10. Vleeming A, Pool-Goudzwaard AL, Hammudoghlu D, Stoeckart R, Snijders CJ, Mens JM. The function of the long dorsal sacroiliac ligament: its implication for understanding low back pain. Spine (Phila Pa 1976) 1996; 21: 556-62.

11. Wong M, Sinkler M, Kiel J. Anatomy, abdomen and pelvis, sacroiliac joint [Internet]. Treasure Island (FL): StatPearls Publishing; 2020. Available at: http://www.ncbi.nlm.nih. 
gov/books/NBK507801/.

12. Becker I, Woodley SJ, Stringer MD. The adult human pubic symphysis: a systematic review. J Anat 2010; 217: 475-87.

13. Vilensky JA, O'Connor BL, Fortin JD, Merkel GJ, Jimenez AM, Scofield BA, et al. Histologic analysis of neural elements in the human sacroiliac joint. Spine (Phila Pa 1976) 2002; 27: 1202-7.

14. Cunningham DJ, Romanes GJ. Cunningham's textbook of anatomy. 12th ed. Oxford, Oxford University Press. 1981, pp 691-2.

15. Forst SL, Wheeler MT, Fortin JD, Vilensky JA. The sacroiliac joint: anatomy, physiology and clinical significance. Pain Physician 2006; 9: 61-7.

16. Holm S, Indahl A, Solomonow M. Sensorimotor control of the spine. J Electromyogr Kinesiol 2002; 12: 219-34.

17. Patel N, Gross A, Brown L, Gekht G. A randomized, placebocontrolled study to assess the efficacy of lateral branch neurotomy for chronic sacroiliac joint pain. Pain Med 2012; 13: 383-98.

18. Alderink GJ. The sacroiliac joint: review of anatomy, mechanics, and function. J Orthop Sports Phys Ther 1991; 13: 71-84.

19. Kampen WU, Tillmann B. Age-related changes in the articular cartilage of human sacroiliac joint. Anat Embryol (Berl) 1998; 198: 505-13.

20. Rawlings CE 3rd, Wilkins RH, Martinez S, Wilkinson RH Jr. Osteoporotic sacral fractures: a clinical study. Neurosurgery 1988; 22(1 Pt 1): 72-6.

21. Prassopoulos PK, Faflia CP, Voloudaki AE, Gourtsoyiannis NC. Sacroiliac joints: anatomical variants on CT. J Comput Assist Tomogr 1999; 23: 323-7.

22. Andersson GB. Epidemiological features of chronic low-back pain. Lancet 1999; 354: 581-5.

23. Bernard TN, Cassidy JD. The sacroiliac joint syndrome: pathophysiology, diagnosis and management. In: The adult spine: principles and practice. Edited by Frymoyer J. New York, Raven Press. 1991, pp 2107-30.

24. Verrills P, Vivian D. Interventions in chronic low back pain. Aust Fam Physician 2004; 33: 421-6.

25. Dreyfuss P, Dryer S, Griffin J, Hoffman J, Walsh N. Positive sacroiliac screening tests in asymptomatic adults. Spine (Phila Pa 1976) 1994; 19: 1138-43.

26. Hill JA, Lombardo SJ. Ankylosing spondylitis presenting as shoulder pain in an athlete. A case report. Am J Sports Med 1981; 9: 262-4.

27. Kok HK, Mumtaz A, O'Brien C, Kane D, Torreggiani WC, Delaney $\mathrm{H}$. Imaging the patient with sacroiliac pain. Can Assoc Radiol J 2016; 67: 41-51.

28. Ramlakan RJ, Govender S. Sacroiliac joint tuberculosis. Int Orthop 2007; 31: 121-4.

29. Hanly JG, Mitchell MJ, Barnes DC, MacMillan L. Early recognition of sacroiliitis by magnetic resonance imaging and single photon emission computed tomography. J Rheumatol 1994; 21: 2088-95.

30. Bakker P, Moltó A, Etcheto A, Van den Bosch F, Landewé R, van Gaalen F, et al. The performance of different classification criteria sets for spondyloarthritis in the worldwide ASAS-COMOSPA study. Arthritis Res Ther 2017; 19: 96.

31. Rudwaleit M, Jurik AG, Hermann KG, Landewé R, van der Heijde D, Baraliakos X, et al. Defining active sacroiliitis on magnetic resonance imaging (MRI) for classification of axial spondyloarthritis: a consensual approach by the ASAS/ OMERACT MRI group. Ann Rheum Dis 2009; 68: 1520-7.

32. Tarantino A, Jablonska JP, D'Aprile P. All that glitters is not gold: sacroiliitis. Reumatologia 2018; 56: 289-93.

33. Zelle BA, Gruen GS, Brown S, George S. Sacroiliac joint dysfunction: evaluation and management. Clin J Pain 2005; 21: 446-55.

34. Cusi M, Saunders J, Van der Wall H, Fogelman I. Metabolic disturbances identified by SPECT-CT in patients with a clinical diagnosis of sacroiliac joint incompetence. Eur Spine J 2013; 22: 1674-82.

35. Klang E, Lidar M, Lidar Z, Aharoni D, Eshed I. Prevalence and awareness of sacroiliac joint alterations on lumbar spine CT in low back pain patients younger than 40 years. Acta Radiol 2017; 58: 449-55.

36. Song R, Lee S, Lee SH. Progressive sacroiliitis due to accessory sacroiliac joint mimicking ankylosing spondylitis: a case report. Medicine (Baltimore) 2019; 98: el5324.

37. Toussirot E, Aubry S, Runge M. Unilateral accessory sacroiliac joint with bone marrow edema mimicking sacroiliitis. J Rheumatol 2018; 45: 1327-8.

38. Chou LH, Slipman CW, Bhagia SM, Tsaur L, Bhat AL, Isaac $\mathrm{Z}$, et al. Inciting events initiating injection-proven sacroiliac joint syndrome. Pain Med 2004; 5: 26-32.

39. Itz CJ, Willems PC, Zeilstra DJ, Huygen FJ. Dutch multidisciplinary guideline for invasive treatment of pain syndromes of the lumbosacral spine. Pain Pract 2016; 16: 90-110.

40. Prather H. Sacroiliac joint pain: practical management. Clin J Sport Med 2003; 13: 252-5.

41. Timm KE. Sacroiliac joint dysfunction in elite rowers. J Orthop Sports Phys Ther 1999; 29: 288-93.

42. Lindsay DM, Meeuwisse WH, Vyse A, Mooney ME, Summersides J. Lumbosacral dysfunctions in elite cross-country skiers. J Orthop Sports Phys Ther 1993; 18: 580-5.

43. Hill JJ, Keating JL. A systematic review of the incidence and prevalence of low back pain in children. Phys Ther Rev 2009; 14: $272-84$

44. Šarčević Z, Tepavčević A. Association between adolescent idiopathic scoliosis and sacroiliac joint dysfunction in young athletes: a case control study. Medicine (Baltimore) 2019; 98: e15161.

45. Miller TL, Cass N, Siegel C. Ankylosing spondylitis in an athlete with chronic sacroiliac joint pain. Orthopedics 2014; 37: 
e207-10.

46. Polsunas PJ, Sowa G, Fritz JM, Gentili A, Morone NE, Raja $\mathrm{SN}$, et al. Deconstructing chronic low back pain in the older adult-step by step evidence and expert-based recommendations for evaluation and treatment: part X: sacroiliac joint syndrome. Pain Med 2016; 17: 1638-47.

47. Chakrabortty S, Kumar S, Gupta D, Rudraraju S. Intractable sacroiliac joint pain treated with peripheral nerve field stimulation. J Anaesthesiol Clin Pharmacol 2016; 32: 392-4.

48. Cairns KD, McRoberts WP, Deer T. Peripheral nerve stimulation for the treatment of truncal pain. Prog Neurol Surg 2011; 24: 58-69.

49. Shim JH, Jeon WJ, Cho SY, Yeom JH, Shin WJ, Kim KH. Sacroiliac joint injection in patients with low back pain or buttock pain: short-term follow-up results. Korean J Pain 2003; 16: 175-80.

50. Simopoulos TT, Manchikanti L, Gupta S, Aydin SM, Kim CH, Solanki D, et al. Systematic review of the diagnostic accuracy and therapeutic effectiveness of sacroiliac joint interventions. Pain Physician 2015; 18: E713-56.

51. Scholten PM, Patel SI, Christos PJ, Singh JR. Short-term efficacy of sacroiliac joint corticosteroid injection based on arthrographic contrast patterns. PMR 2015; 7: 385-91.

52. Mayo Foundation for Medical Education and Research. Sacroiliitis [Internet]. Rochester (MN): Mayo Foundation for Medical Education and Research; 2018. Available at: https:// www.mayoclinic.org/diseases-conditions/sacroiliitis/diagnosis-treatment/drc-20350751.

53. Manchikanti L, Abdi S, Atluri S, Benyamin RM, Boswell MV, Buenaventura RM, et al. An update of comprehensive evidence-based guidelines for interventional techniques in chronic spinal pain. Part II: guidance and recommendations. Pain Physician 2013; 16(2 Suppl): S49-283.

54. Sachs D, Capobianco R. Minimally invasive sacroiliac joint fusion: one-year outcomes in 40 patients. Adv Orthop 2013; 2013: 536128.

55. Sachs D, Kovalsky D, Redmond A, Limoni R, Meyer SC, Harvey $C$, et al. Durable intermediate-to long-term outcomes after minimally invasive transiliac sacroiliac joint fusion using triangular titanium implants. Med Devices (Auckl) 2016; 9: 213-22.

56. Rudolf L, Capobianco R. Five-year clinical and radiographic outcomes after minimally invasive sacroiliac joint fusion using triangular implants. Open Orthop J 2014; 8: 375-83.

57. Vanaclocha V, Herrera JM, Sáiz-Sapena N, Rivera-Paz M, Verdú-López F. Minimally invasive sacroiliac joint fusion, radiofrequency denervation, and conservative management for sacroiliac joint pain: 6-year comparative case series. Neurosurgery 2018; 82: 48-55.

58. Brown CR, Reiner SL. Genes outside the major histocompatibility complex control resistance and susceptibility to experimental Lyme arthritis. Med Microbiol Immunol 2000;
189: 85-90.

59. Schlosstein L, Terasaki PI, Bluestone R, Pearson CM. High association of an HL-A antigen, W27, with ankylosing spondylitis. N Engl J Med 1973; 288: 704-6.

60. Brewerton DA, Hart FD, Nicholls A, Caffrey M, James DC, Sturrock RD. Ankylosing spondylitis and HL-A 27. Lancet 1973; 1: 904-7.

61. Orchard TR, Holt H, Bradbury L, Hammersma J, McNally E, Jewell DP, et al. The prevalence, clinical features and association of HLA-B27 in sacroiliitis associated with established Crohn's disease. Aliment Pharmacol Ther 2009; 29: 193-7.

62. Alkan S, Kayiran N, Zengin O, Kalem A, Kimyon G, Kilinc EO, et al. Isotretinoin-induced spondyloarthropathy-related symptoms: a prospective study. J Rheumatol 2015; 42: 2106-9.

63. Faustini F, Zoli A, Ferraccioli GF. Immunologic and genetic links between spondylarthropathies and inflammatory bowel diseases. Eur Rev Med Pharmacol Sci 2009; 13 Suppl 1: 1-9.

64. Eksioglu E, Oztekin F, Unlu E, Cakci A, Keyik B, Karadavut IK. Sacroiliitis and polyneuropathy during isotretinoin treatment. Clin Exp Dermatol 2008; 33: 122-4.

65. Kașifoğlu T, Calișir C, Cansu DU, Korkmaz C. The frequency of sacroiliitis in familial Mediterranean fever and the role of HLA-B27 and MEFV mutations in the development of sacroiliitis. Clin Rheumatol 2009; 28: 41-6.

66. van de Loo FA, Joosten LA, van Lent PL, Arntz OJ, van den Berg WB. Role of interleukin-1, tumor necrosis factor alpha, and interleukin-6 in cartilage proteoglycan metabolism and destruction. Effect of in situ blocking in murine antigen- and zymosan-induced arthritis. Arthritis Rheum 1995; 38: 16472 .

67. Dale M, Nicklin MJ. Interleukin-1 receptor cluster: gene organization of IL1R2, IL1R1, IL1RL2 (IL-1Rrp2), IL1RL1 (T1/ ST2), and IL18R1 (IL-1Rrp) on human chromosome 2q. Genomics 1999; 57: 177-9.

68. Colotta F, Re F, Muzio M, Bertini R, Polentarutti N, Sironi M, et al. Interleukin-1 type II receptor: a decoy target for IL-1 that is regulated by IL-4. Science 1993; 261: 472-5.

69. Jiang Y, Genant HK, Watt I, Cobby M, Bresnihan B, Aitchison $\mathrm{R}$, et al. A multicenter, double-blind, dose-ranging, randomized, placebo-controlled study of recombinant human interleukin-1 receptor antagonist in patients with rheumatoid arthritis: radiologic progression and correlation of Genant and Larsen scores. Arthritis Rheum 2000; 43: 1001-9.

70. McGarry F, Neilly J, Anderson N, Sturrock R, Field M. A polymorphism within the interleukin 1 receptor antagonist (IL$1 \mathrm{Ra}$ ) gene is associated with ankylosing spondylitis. Rheumatology (Oxford) 2001; 40: 1359-64.

71. Zhang P, Li Q, Qi J, Lv Q, Zheng X, Wu X, et al. Association between vitamin $\mathrm{D}$ receptor gene polymorphism and ankylosing spondylitis in Han Chinese. Int J Rheum Dis 2017; 20: 1510-6. 
72. Davidson SI, Jiang L, Cortes A, Wu X, Glazov EA, Donskoi $M$, et al. Brief report: high-throughput sequencing of IL23R reveals a low-frequency, nonsynonymous single-nucleotide polymorphism that is associated with ankylosing spondylitis in a Han Chinese population. Arthritis Rheum 2013; 65: 174752.

73. Burton PR, Clayton DG, Cardon LR, Craddock N, Deloukas P, Duncanson A, et al. Association scan of 14,500 nonsynonymous SNPs in four diseases identifies autoimmunity variants. Nat Genet 2007; 39: 1329-37.

74. Wellcome Trust Case Control Consortium, Australo-AngloAmerican Spondylitis Consortium (TASC). A genome-wide association study identifies IL23R as an inflammatory bowel disease gene. Science 2006; 314: 1461-3.

75. Nair RP, Duffin KC, Helms C, Ding J, Stuart PE, Goldgar D, et al. Genome-wide scan reveals association of psoriasis with IL-23 and NF-kappaB pathways. Nat Genet 2009; 41: 199-204.

76. Kadi A, Costantino F, Izac B, Leboime A, Said-Nahal R, Garchon HJ, et al. Brief report: the IL23R nonsynonymous polymorphism rs11209026 is associated with radiographic sacroiliitis in spondyloarthritis. Arthritis Rheum 2013; 65: 2655-60.

77. Gorman JD, Sack KE, Davis JC Jr. Treatment of ankylosing spondylitis by inhibition of tumor necrosis factor alpha. $\mathrm{N}$ Engl J Med 2002; 346: 1349-56.

78. Braun J, Brandt J, Listing J, Zink A, Alten R, Golder W, et al. Treatment of active ankylosing spondylitis with infliximab: a randomised controlled multicentre trial. Lancet 2002; 359: 1187-93.

79. Redlich K, Görtz B, Hayer S, Zwerina J, Kollias G, Steiner G, et al. Overexpression of tumor necrosis factor causes bilateral sacroiliitis. Arthritis Rheum 2004; 50: 1001-5.

80. Peeters H, Vander Cruyssen B, Laukens D, Coucke P, Marichal D, Van Den Berghe M, et al. Radiological sacroiliitis, a hallmark of spondylitis, is linked with CARD15 gene polymorphisms in patients with Crohn's disease. Ann Rheum Dis 2004; 63: 1131-4.

81. Peeters H, Vander Cruyssen B, Mielants H, de Vlam K, Vermeire S, Louis E, et al. Clinical and genetic factors associated with sacroiliitis in Crohn's disease. J Gastroenterol Hepatol 2008; 23: 132-7.

82. Wright C, Sibani S, Trudgian D, Fischer R, Kessler B, LaBaer $\mathrm{J}$, et al. Detection of multiple autoantibodies in patients with ankylosing spondylitis using nucleic acid programmable protein arrays. Mol Cell Proteomics 2012; 11: M9.00384.

83. Zolnierowicz S. Type $2 \mathrm{~A}$ protein phosphatase, the complex regulator of numerous signaling pathways. Biochem Pharmacol 2000; 60: 1225-35.

84. Duan X, Liang YY, Feng XH, Lin X. Protein serine/threonine phosphatase PPM1A dephosphorylates Smad1 in the bone morphogenetic protein signaling pathway. J Biol Chem 2006; 281: 36526-32.
85. Kim YG, Sohn DH, Zhao X, Sokolove J, Lindstrom TM, Yoo B, et al. Role of protein phosphatase magnesium-dependent $1 \mathrm{~A}$ and anti-protein phosphatase magnesium-dependent $1 \mathrm{~A}$ autoantibodies in ankylosing spondylitis. Arthritis Rheumatol 2014; 66: 2793-803.

86. Singh Sangha M, Wright ML, Ciurtin C. Strongly positive anti-CCP antibodies in patients with sacroiliitis or reactive arthritis post-E. coli infection: a mini case-series based review. Int J Rheum Dis 2018; 21: 315-21.

87. Prajzlerová $K$, Grobelná $K$, Hušáková $M$, Forejtová Š, Jüngel A, Gay S, et al. Association between circulating miRNAs and spinal involvement in patients with axial spondyloarthritis. PLoS One 2017; 12: e0185323.

88. Huang J, Song G, Yin Z, Luo X, Ye Z. Elevated miR-29a expression is not correlated with disease activity index in PBMCs of patients with ankylosing spondylitis. Mod Rheumatol 2014; 24: 331-4.

89. Li X, Lv Q, Tu L, Zhao M, Zhang P, Li Q, et al. Aberrant expression of microRNAs in peripheral blood mononuclear cells as candidate biomarkers in patients with axial spondyloarthritis. Int J Rheum Dis 2019; 22: 1188-95.

90. Mielants H, Veys EM, Cuvelier C, De Vos M, Goemaere S, De Clercq L, et al. The evolution of spondyloarthropathies in relation to gut histology. II. Histological aspects. J Rheumatol 1995; 22: 2273-8.

91. Alonso Farto JC, Arias IA, Lopez Longo FJ, Gonzalez Fernandez CM, Monteagudo Saez I, Ortega Valle A, et al. Clinical significance of abdominal scintigraphy using $99 \mathrm{mTc}$ HMPAO-labelled leucocytes in patients with seronegative spondyloarthropathies. Eur J Nucl Med 2000; 27: 1768-73.

92. Fox JG, Dewhirst FE, Fraser GJ, Paster BJ, Shames B, Murphy JC. Intracellular Campylobacter-like organism from ferrets and hamsters with proliferative bowel disease is a Desulfovibrio sp. J Clin Microbiol 1994; 32: 1229-37.

93. Hannu T. Reactive arthritis. Best Pract Res Clin Rheumatol 2011; 25: 347-57.

94. Schiellerup P, Krogfelt KA, Locht H. A comparison of selfreported joint symptoms following infection with different enteric pathogens: effect of HLA-B27. J Rheumatol 2008; 35: 480-7.

95. Putterman C, Rubinow A. Reactive arthritis associated with Clostridium difficile pseudomembranous colitis. Semin Arthritis Rheum 1993; 22: 420-6.

96. Stoll ML, Weiss PF, Weiss JE, Nigrovic PA, Edelheit BS, Bridges SL Jr, et al. Age and fecal microbial strain-specific differences in patients with spondyloarthritis. Arthritis Res Ther 2018; 20: 14.

97. Ebringer A. The cross-tolerance hypothesis, HLA-B27 and ankylosing spondylitis. Br J Rheumatol 1983; 22(4 Suppl 2): 53-66.

98. Rath HC, Wilson KH, Sartor RB. Differential induction of colitis and gastritis in HLA-B27 transgenic rats selectively 
colonized with Bacteroides vulgatus or Escherichia coli. Infect Immun 1999; 67: 2969-74.

99. Baeten D, De Keyser F, Mielants H, Veys EM. Immune link- ages between inflammatory bowel disease and spondyloarthropathies. Curr Opin Rheumatol 2002; 14: 342-7. 